\title{
Metabolic Fate of Cysteine Sulfur in Growing Rats at Various Dietary Protein Levels
}

\author{
Hideyuki Tanaka, Kiyotaka TaKahashi, and Masaji Ogura \\ Department of Agricultural Chemistry, Faculty of Agriculture, \\ Utsunomiya University, Utsunomiya 321, Japan
}

(Received June 2, 1993)

\begin{abstract}
Summary The metabolic fate of $\mathrm{L}-\left[{ }^{35} \mathrm{~S}\right]$ cysteine was investigated in growing rats fed on diets containing graded levels of protein calorie percentages $(0,5,10,15$, and $30 \mathrm{PC} \%)$ by use of purified whole egg protein at $4,100 \mathrm{kcal}$ of metabolizable energy per kilogram of diet. Incorporation of radioactivity into body protein during the $12 \mathrm{~h}$ period after intraperitoneal injection of ${ }^{35} \mathrm{~S}$-cysteine was about $70 \%$ of the dose in the 0 to $15 \mathrm{PC} \%$ group, but it decreased significantly in the $30 \mathrm{PC} \%$ group, showing a break point at around $15 \mathrm{PC} \%$ in the diet. A considerable amount of the radioactivity was recovered in the carcass soluble fraction in which the label in the taurine fraction gradually in creased with increasing dietary protein levels from 0 to $30 \mathrm{PC} \%$. Urinary excretion of total ${ }^{35} \mathrm{~S}$ during the $12 \mathrm{~h}$ period was depressed in the lower $\mathrm{PC} \%$ groups, but it increased in the $30 \mathrm{PC} \%$ group, about $23 \%$ of the dose being recovered. More than 50\% of the urinary radioactivity was present in the inorganic sulfate fraction, but less than $10 \%$ was in the taurine fraction. These results indicate that cysteine sulfur is preferentially utilized for body protein synthesis, especially in dietary protein depletion, and that the oxidation of cysteine sulfur to taurine and inorganic sulfate is elevated with higher $\mathrm{PC} \%$ in the diet. The response pattern of cysteine sulfur metabolism to dietary protein intake resembled that of cysteine carbon metabolism which was previously reported.
\end{abstract}

Key Words amino acid metabolism, cysteine sulfur, taurine, urinary sulfate

Cyst(e)ine is nonessential for the growth of rats and other mammals, since this amino acid can be synthesized de novo where cysteine sulfur is derived from methionine and its carbon skeleton from serine (1). Rose and Wixom (2) have reported that about one-third of the methionine requirement of the growing rat can be satisfied by cystine. Cysteine sulfur is catabolized mainly by two pathways, a) to cysteine sulfinic acid in a reaction catalyzed by cysteine dioxygenase and b) to reduced inorganic sulfur catalyzed by cysteine desulfhydrase $(1,3)$. The dietary 
modulation of these cysteine catabolic pathways was extensively investigated by Stipanuk et al. (4-6) and Yamaguchi et al. (7,8). Daniels and Stipanuk (5) reported that the cysteine sulfinate pathway plays a major regulatory role in cysteine degradation.

In the previous experiments (9-19), we reported the metabolic fates of carbon skeletons of individual amino acids in growing rats fed on diets with graded levels of purified whole egg protein in relation to the protein and energy metabolism. It was found that the carbon skeleton of ${ }^{14} \mathrm{C}$-cysteine was preferentially utilized for body protein synthesis especially in dietary protein depletion, and that a significant amount of cysteine carbon was converted to taurine, a part of which was excreted into urine when excess dietary protein was given (17). In this paper, we studied the effect of dietary protein levels on the response pattern of cysteine sulfur metabolism in growing rats by measuring the distribution of ${ }^{35} \mathrm{~S}$-cysteine in body components and urine.

\section{MATERIALS AND METHODS}

Animals and diets. Male Wistar rats were preliminarily fed a stock diet (MF, Oriental Yeast Co.) until mean body weight had reached around $80 \mathrm{~g}$. Animals were housed in individual stainless wire-mesh cages at $23 \pm 1^{\circ} \mathrm{C}$ in a temperaturecontrolled room with a $12 \mathrm{~h}$ light, $12 \mathrm{~h}$ dark cycle, the light cycle being from $6: 00$ to $18: 00$. Food and water were given ad libitum for 10 days. The experimental diets contained $0,55,111,166$, and $332 \mathrm{~g}$ of purified whole egg protein (20) per kilogram, as the $0,5,10,15$, and $30 \mathrm{PC} \%$ diets, respectively. All diets contained $100 \mathrm{~g}$ of lard, $50 \mathrm{~g}$ of cellulose powder, $40 \mathrm{~g}$ of salt mixture, $10 \mathrm{~g}$ of vitamin mixture, and enough corn starch to complete $1 \mathrm{~kg}$. The protein calorie percentage (PC\%) means the proportion of metabolizable energy of dietary protein to the total metabolizable energy of the diet $(21)$, i.e. $4,100 \mathrm{kcal}$ per kilogram of diet in this experiment.

Isotope experiments. On the last day of feeding, the rats were starved for $9 \mathrm{~h}$, from $12: 00$ to $21: 00$, and then given the same experimental diets for $3 \mathrm{~h}$, from $21: 00$ to 24:00. After this feeding, $\mathrm{L}-\left[{ }^{35} \mathrm{~S}\right]$ cysteine in a saline solution (1.70 $\mathrm{GBq} / \mathrm{mmol}$, Amersham Japan) was administered by intraperitoneal injection. The standard dosage was $153.9 \mathrm{kBq} / 0.4 \mathrm{ml} / 100 \mathrm{~g}$ of body weight. Immediately following the injection, each animal was placed in a glass metabolism apparatus, and offered only water. Expired gas was washed at $2 \mathrm{~h}$ intervals in $0.6 \% \mathrm{Zn}$-acetate solution, and urine was collected in 5\% acetic acid during the $12 \mathrm{~h}$ period of the isotope experiment. Radioactivity was measured in a liquid scintillation spectrometer (Aloka LSC-900) using an NT (nonione-toluene) scintillation solution containing $4 \mathrm{~g}$ of DPO per liter of 3 parts of nonylphenoxy polyethoxy ethanol and 7 parts of toluene (22). The efficiency of the counting system was estimated for each sample by an external standard ratio method, and ${ }^{35} \mathrm{~S}$ decay (half-life: 87.4 days) was corrected in each assay. The radioactivities in total ${ }^{35} \mathrm{~S},{ }^{35} \mathrm{~S}$-taurine and inorganic 
${ }^{35} \mathrm{~S}$-sulfate of the urine were measured by a slight modification of the method of Stipanuk (4). Non-labeled taurine (about $0.5 \mathrm{mg}$ ) was added as a carrier to each sample of urine, and then the mixture was treated with $3 \%$ sulfosalicylic acid overnight and centrifuged at 3,000 rpm for $15 \mathrm{~min}$. The deproteinized urine supernatant was put on the top of the combined columns of Dowex $50 \times 8(200-400$ mesh, $\mathrm{H}^{+}$form, $\left.1.5 \times 2 \mathrm{~cm}\right)$ and Dowex $1 \times 2(200-400$ mesh, acetate form, $1.5 \times$ $2 \mathrm{~cm}$ ) which were assembled in a series. The columns were washed with $30 \mathrm{ml}$ of $0.1 \mathrm{~N}$ acetic acid, the eluate being called the taurine fraction. The amino acid fraction containing small peptides was obtained by eluting the Dowex $50 \times 8$ column with $15 \mathrm{ml}$ of $3 \mathrm{~N}$ ammonia. To measure the amount of label incorporated into urinary inorganic sulfate, duplicate tubes containing $2 \mathrm{ml}$ of urine plus $1 \mathrm{ml}$ of $2 \% \mathrm{Na}_{2} \mathrm{SO}_{4}$ (as a carrier) were prepared; $1 \mathrm{ml}$ of $10 \% \mathrm{BaCl}_{2}$ was added to one tube, and $1 \mathrm{ml}$ of water was added to the other. After centrifugation at 3,000 rpm for 10 min, $1 \mathrm{ml}$ of the supernatant from each tube was counted. The urinary ${ }^{35} \mathrm{SO}_{4}$ that was precipitated as $\mathrm{Ba}^{35} \mathrm{SO}_{4}$ was assumed to be the difference in radioactivity in the supernatant of the tubes to which $\mathrm{BaCl}_{2}$ was and was not added.

Tissue analyses. Animals were killed by decapitation $12 \mathrm{~h}$ after administration of the isotopes. The liver was removed, and shed blood was combined with the carcass. The carcass and liver were homogenized and analyzed for radioactivity in their major components such as the protein, lipid, and soluble fractions, details of which were described previously $(9,14)$. A portion of the homogenate was extracted with chloroform-methanol mixture $(2: 1, \mathrm{v} / \mathrm{v})$ to obtain the lipid fraction, and then the residue was extracted with cold 10\% trichloroacetic acid (TCA). The extract was combined with the upper phase solution by Folch's washing method (23) to obtain the soluble fraction of the sample. The TCA insoluble residue was dissolved in $2 \mathrm{~N} \mathrm{NaOH}$ solution as the protein fraction. The radioactivity in each fraction was measured as described above.

To examine the distribution of ${ }^{35} \mathrm{~S}$ in the soluble fraction, a sample of the carcass soluble fraction was evaporated, extracted with diethyl ether to remove TCA, and then chromatographed by the Dowex $50 \times 8$ and Dowex $1 \times 2$ columns as described previously (17). The assembled columns were washed with $0.1 \mathrm{~N}$ acetic acid, the eluate being the taurine fraction. After washing the columns, they were taken to pieces and then the Dowex $50 \times 8$ column was eluted with $3 \mathrm{~N}$ ammonia, the eluate being the amino acid fraction, and the Dowex $1 \times 2$ column was eluted with $2 \mathrm{~N} \mathrm{HCl}$, the eluate being the acidic fraction. The radioactivity of each fraction was measured in a NT scintillation solution.

Statistical analysis. The results were tested by an analysis of variance, and Tukey's procedure for multiple comparisons was used to evaluate the statistical significance with a probability level of 0.05 (24).

\section{RESULTS}

The growth curves of the 10, 15, and 30 PC $\%$ groups were almost linear, while 


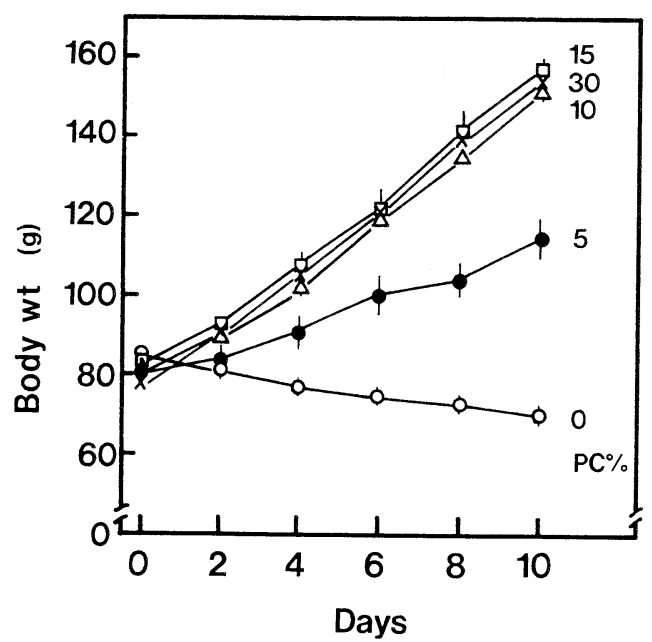

Fig. 1. Growth curves of rats fed on diets of various protein calories percentages.

that of the $5 \mathrm{PC} \%$ group was retarded slightly during the early days of the experimental period (Fig. 1). The body weight gain reached its approximate maximum with around $10 \mathrm{PC} \%$ in the diet. The results of the growth experiment were essentially identical to those obtained in our previous experiments, in which body protein retention reached a plateau and body lipid retention attained a maximum with around $10 \mathrm{PC} \%$ in the diet (10). As has been pointed out, no drastic change in pool size of tissue amino acid was induced by the injection of the isotope, since only a trace of labeled amino acid was used (17). The total recovery percentages of the ${ }^{35} \mathrm{~S}$ in the $0,5,10,15$, and $30 \mathrm{PC} \%$ groups were $96.2,96.3,98.2$, 97.9 , and $98.5 \%$, respectively (the means of three to four rats in each group).

No radioactivity was detected in expired gas which was washed in $0.6 \%$ $\mathrm{Zn}$-acetate solution during the $12 \mathrm{~h}$ period after intraperitoneal injection of $\mathrm{L}-{ }^{35} \mathrm{~S}-\mathrm{cysteine}$. Urinary excretion of the radioactivity from ${ }^{35} \mathrm{~S}$-cysteine was low in the 0 to $15 \mathrm{PC} \%$ groups and it increased to the great extent in the $30 \mathrm{PC} \%$ group, about $23 \%$ of the dose being recovered (Table 1). To characterize the radioactive compounds excreted in the urine after injection of labeled cysteine, we examined the distribution of radioactivity in their metabolites as described in MATERIALS AND Methods. More than $50 \%$ of the ${ }^{35} \mathrm{~S}$ excreted in the urine was present in the inorganic sulfate fraction over the whole range of dietary protein calorie percentages. The values increased with increasing dietary protein levels and about $80 \%$ of urinary label was excreted as sulfate in the $30 \mathrm{PC} \%$ group. The recovery of radioactivity in the taurine fraction was reduced in the lower $\mathrm{PC} \%$ groups and increased with higher $\mathrm{PC} \%$, about $10 \%$ of the urinary ${ }^{35} \mathrm{~S}$ being recovered in the 30 PC\% group. The radioactivity in the amino acid and peptide fraction was promptly examined by ion-exchange chromatography, and about 35 and $16 \%$ of the urinary ${ }^{35} \mathrm{~S}$ were accounted for in the 0 and $5 \mathrm{PC} \%$ groups, respectively (data not 
Table 1. Urinary excretion of total ${ }^{35} \mathrm{~S},\left[{ }^{35} \mathrm{~S}\right]$ sulfate, and $\left[{ }^{35} \mathrm{~S}\right]$ taurine after injecting $\mathrm{L}-\left[{ }^{35} \mathrm{~S}\right]$ cysteine in rats fed on diets of various dietary protein calorie percentages.

\begin{tabular}{cccc}
\hline \multirow{2}{*}{$\begin{array}{c}\text { Dietary } \\
\text { group } \\
(\mathrm{PC} \%)\end{array}$} & $\begin{array}{c}\text { Total }{ }^{35} \mathrm{~S} \\
(\% \text { of the dose })\end{array}$ & $\begin{array}{c}{\left[{ }^{35} \mathrm{~S}\right] \text { Sulfate }} \\
\left(\% \text { of total }{ }^{35} \mathrm{~S}\right)\end{array}$ & $\begin{array}{c}{\left[{ }^{35} \mathrm{~S}\right] \text { Taurine }} \\
\left(\% \text { of total }{ }^{35} \mathrm{~S}\right)\end{array}$ \\
\cline { 2 - 4 } & $6.4 \pm 2.4$ & $52.8 \pm 6.6$ & $3.2 \pm 0.8$ \\
0 & $8.6 \pm 1.3$ & $70.9 \pm 5.2$ & $2.6 \pm 0.5$ \\
5 & $8.0 \pm 1.7$ & $73.4 \pm 3.1$ & $4.2 \pm 1.2$ \\
10 & $8.7 \pm 0.9$ & $69.9 \pm 3.5$ & $6.5 \pm 1.9$ \\
30 & $23.4 \pm 1.9$ & $84.4 \pm 4.1$ & $9.8 \pm 1.7$ \\
\hline Difference & & & 1.0 \\
$(p<0.05)$ & 9.1 & 4.4 & \\
\hline
\end{tabular}

The values are $\mathrm{M} \pm \mathrm{SE}$ for three to four rats. Tukey's test was taken as the criterion of statistical significance with a probability level of 0.05 .

Table 2. Distribution of radioactivity in the protein, lipid, and soluble fractions of carcass and liver from $\mathrm{L}-\left[{ }^{35} \mathrm{~S}\right] \mathrm{cysteine}$ in rats fed on diets of various dietary protein calorie percentages.

\begin{tabular}{|c|c|c|c|c|c|c|}
\hline \multirow{3}{*}{$\begin{array}{c}\text { Dietary } \\
\text { group } \\
(\mathrm{PC} \%)\end{array}$} & \multicolumn{6}{|c|}{ Radioactivity ( $\%$ of the injected dose) } \\
\hline & \multicolumn{2}{|c|}{ Protein } & \multicolumn{2}{|c|}{ Lipid } & \multicolumn{2}{|c|}{ Soluble fraction } \\
\hline & Carcass & Liver & Carcass & Liver & Carcass & Liver \\
\hline 0 & $62.7 \pm 3.4$ & $6.6 \pm 1.1$ & $1.1 \pm 0.05$ & $0.07 \pm 0.01$ & $17.9 \pm 1.7$ & $1.4 \pm 0.2$ \\
\hline 5 & $65.8 \pm 2.5$ & $5.6 \pm 0.7$ & $0.9 \pm 0.08$ & $0.06 \pm 0.01$ & $13.8 \pm 1.2$ & $1.5 \pm 0.1$ \\
\hline 10 & $69.7 \pm 3.1$ & $4.4 \pm 0.6$ & $0.8 \pm 0.08$ & $0.03 \pm 0.01$ & $14.5 \pm 0.8$ & $0.8 \pm 0.3$ \\
\hline 15 & $64.3 \pm 1.6$ & $2.6 \pm 0.1$ & $0.6 \pm 0.02$ & $0.02 \pm 0.00$ & $20.2 \pm 0.3$ & $1.5 \pm 0.5$ \\
\hline 30 & $48.7 \pm 0.9$ & $2.0 \pm 0.2$ & $0.5 \pm 0.01$ & $0.03 \pm 0.00$ & $21.7 \pm 0.7$ & $2.2 \pm 0.7$ \\
\hline $\begin{array}{l}\text { Difference } \\
\qquad(p<0.05)\end{array}$ & 14.1 & 3.5 & 0.3 & 0.04 & 6.5 & NS \\
\hline
\end{tabular}

The values are $\mathrm{M} \pm \mathrm{SE}$ for three to four rats. Tukey's test was taken as the criterion of statistical significance with a probability level of 0.05 . NS: not significant.

shown).

Incorporation of ${ }^{35} \mathrm{~S}$-cysteine into the carcass protein was more than $60 \%$ of the dose in the 0 to $15 \mathrm{PC} \%$ groups but decreased in the $30 \mathrm{PC} \%$ group (Table 2). ${ }^{35} \mathrm{~S}$ incorporation into the liver protein was high in the $0 \mathrm{PC} \%$ group and the value decreased gradually with increasing dietary protein levels, showing a somewhat different response pattern to that of the carcass protein. The incorporation of cysteine sulfur into the carcass and liver lipid fractions was negligible. The recovery of radioactivity in the carcass soluble fraction was about $15 \%$ of the dose in both 5 and 10 PC\% groups, and increased in the 15 and 30 PC\% groups, more 


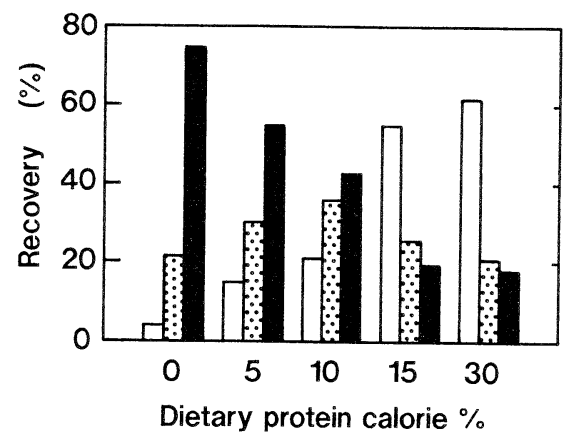

Fig. 2. Distribution of radioactivity in the taurine, amino acid, and organic acid fractions from the carcass soluble fraction after injecting $L-\left[{ }^{35} \mathrm{~S}\right]$ cysteine. A pooled sample of the carcass soluble fraction from each group was analyzed by the ion-exchange chromatography. amino acid fraction; $\left[\begin{array}{ll}\text {, a } \\ \text {, acidic }\end{array}\right.$ fraction; $\square$, taurine fraction.

than $20 \%$ of the dose being recovered. Small amount of ${ }^{35} \mathrm{~S}$ was recovered in the liver soluble fraction, and no significant differences were observed between dietary groups.

Because of the large amount of radioactivity in the carcass soluble fraction, this fraction from a pooled sample of each dietary group was further analyzed by ion-exchange chromatography on Dowex 50 and Dowex 1 columns. The distribution of radioactivity in the amino acid fraction (adsorbed by Dowex 50 resin), the acidic fraction (adsorbed by Dowex 1 resin), and the taurine fraction (nonadsorbed by either Dowex 50 or Dowex 1 resins) was examined (Fig. 2). In the amino acid fraction, more than $70 \%$ of the ${ }^{35} \mathrm{~S}$ recovered in the carcass soluble fraction was recovered in the 0 PC $\%$ group, but the values in the higher PC\% groups gradually decreased with increasing $\mathrm{PC} \%$. Radioactivity in the taurine fraction was reduced at $0 \mathrm{PC} \%$, but increased linearly with increasing dietary protein levels, about $60 \%$ of the ${ }^{35} \mathrm{~S}$ being recovered in the $30 \mathrm{PC} \%$ group. No significant difference in radioactivity was observed in the acidic fraction, where radioactive components were unidentified further.

\section{DISCUSSION}

In this experiment, the metabolic fate of cysteine sulfur was examined in growing rats at various dietary protein calorie percentages, and its metabolic response to dietary protein intake was compared to that of cysteine carbon, obtained in our previous experiment (17). The gross distributions of radioactivity in body protein, body lipid, and body soluble fractions from ${ }^{35} \mathrm{~S}$-cysteine and ${ }^{14} \mathrm{C}$ cysteine are summarized in Fig. 3. The value for each body component was calculated as the total of carcass and liver. By using purified whole egg protein as a dietary protein source, it was possible to investigate the metabolic fate of the 


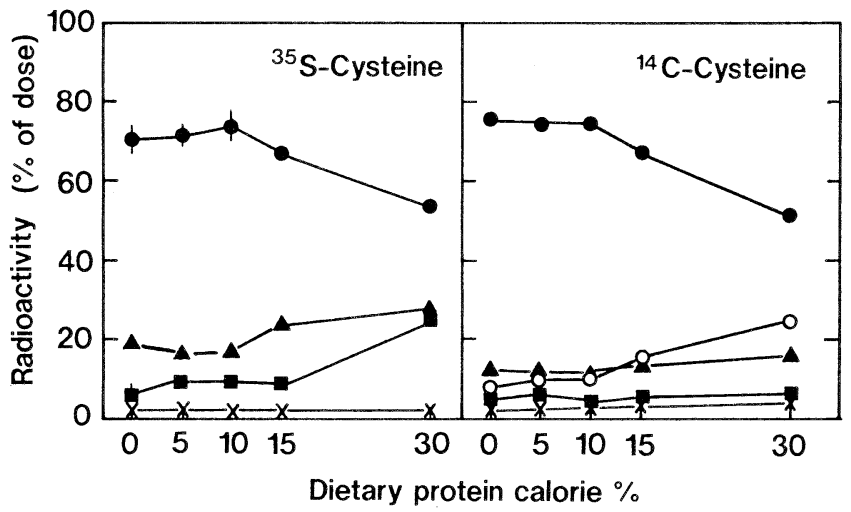

Fig. 3. Gross distribution of radioactivity in rats fed the diets with various protein calorie percentages $12 \mathrm{~h}$ after injecting $\mathrm{L}-\left[{ }^{35} \mathrm{~S}\right]$ cysteine and $\mathrm{L}-\left[\mathrm{U}-{ }^{14} \mathrm{C}\right]$ cysteine. Each value represents the mean for three to four rats, and the vertical bar indicates standard errors of the mean. The data for $\mathrm{L}-\left[\mathrm{U}-{ }^{14} \mathrm{C}\right]$ cysteine is cited from our previous paper (17). $\bigcirc$, expired $\mathrm{CO}_{2} ; \boldsymbol{\ominus}$, body protein; $\times$, body lipid; $\mathbf{A}$, body soluble fraction; $\mathbf{\square}$, urine.

amino acids without inappropriate factors such as limiting amino acid. ${ }^{35} \mathrm{~S}$-Cysteine was incorporated to a great extent into the body protein, especially at lower dietary protein calorie percentages. The response pattern of cysteine sulfur to protein intake resembled that of cysteine carbon. It should be noticed that cysteine which is one of the non-essential amino acids for the growth of rats is primarily utilized for body protein synthesis, by evaluating from both cysteine sulfur and carbon. In our previous studies (9-19), the metabolic fates of the carbon skeletons of 20 individual amino acids were examined in growing rats in relation to the balance data on protein and energy metabolism. These results showed that the carbon skeletons of the essential amino acids were preferentially utilized for body protein synthesis. Much more carbon from cysteine and tyrosine were also incorporated into the body protein and their response patterns to protein intake resembled those of the essential amino acids. In contrast, the carbon skeletons of the nonessential amino acids, alanine, aspartic acid, glutamic acid, and glutamine, were rapidly degraded to expired carbon dioxide even with dietary protein depletion, but incorporated to a lesser extent into the body protein, whereas considerable amounts of glycine, serine, proline, and asparagine were utilized for body protein synthesis rather than for energy production. Thus, the metabolic aspects of carbon skeletons of these amino acids are classified into three groups, showing a systematic pattern that is peculiar to their essentiality and catabolic activity. The conversion of cysteine sulfur to body lipid fraction was negligible in all the dietary groups, and no radioactivity was detected in the expired gases throughout the overall experimental period for $12 \mathrm{~h}$. It appeared that these conversions of cysteine sulfur did not have any metabolic or nutritional significance. 
On the contrary, the conversion of cysteine to taurine may be one of the important metabolic roles of this amino acid. As shown in Fig. 3, in both the experiments with ${ }^{35} \mathrm{~S}$-cysteine and ${ }^{14} \mathrm{C}$-cysteine, considerable amounts of label were recovered in the body soluble fraction in all the dietary groups, in which the proportion of labeled taurine from cysteine sulfur or carbon was elevated extremely in the higher PC\% groups. When ${ }^{35} \mathrm{~S}$-cysteine was injected intraperitoneally, about $60 \%$ of the label in the carcass soluble fraction was converted to taurine in the 30 PC\% group (Fig. 2), while more than 50\% of the label in the soluble fraction was also recovered as taurine when ${ }^{14} \mathrm{C}$-cysteine was injected (17). Urinary excretion of total ${ }^{35} \mathrm{~S}$ was less than $8 \%$ of the dose in the 0 to $15 \mathrm{PC} \%$ groups and it increased to $22 \%$ at $30 \mathrm{PC} \%$ in the diet, while the urinary ${ }^{14} \mathrm{C}$ excretion was 3 to $6 \%$ of the dose in all dietary groups and the expired ${ }^{14} \mathrm{CO}_{2}$ output increased to $25 \%$ of the dose at $30 \mathrm{PC} \%$ in the diet (17). A much higher proportion of ${ }^{35} \mathrm{~S}$ excreted in the urine was recovered as the inorganic sulfate fraction, but less than $10 \%$ of urinary ${ }^{35} \mathrm{~S}$ was present in the taurine fraction. Similar excretion patterns following injection of ${ }^{35} \mathrm{~S}$ cysteine were observed by Stipanuk (4), Daniels and Stipanuk. (5), and Benjamin and Steele (25), who have reported that the cysteine sulfinate pathway plays a major regulatory role in cysteine degradation and that a greater proportion of the cysteine sulfinate formed by the action of cysteine dioxygenase is catabolized by the decarboxylation pathway, which yields taurine, than by the transamination pathway, which yields sulfate, ammonia, and pyruvate in rats fed a large amount of cysteine. However, the results from their experiments and others showed that the ratio of ${ }^{35} \mathrm{SO}_{4}$ to total ${ }^{35} \mathrm{~S}$ was much greater than that of ${ }^{35} \mathrm{~S}$-taurine to total ${ }^{35} \mathrm{~S}$ in urine. Thus, it is necessary to confirm whether cysteine sulfur is mainly catabolized by the taurine pathway or not, especially in dietary protein depletion.

\section{REFERENCES}

1) Meister, A. (1965): Intermediary metabolism of amino acids, in Biochemistry of the Amino Acids, Vol. II, Academic Press, New York, pp. 757-818.

2) Rose, W. C., and Wixom, R. L. (1955): The amino acid requirements of man. XIII. The sparing effect of cystine on the methionine requirement. J. Biol. Chem., 216, 763773.

3) Krebs, H. A. (1964): The metabolic fate of amino acids, in Mammalian Protein Metabolism, Vol. I, ed. by Munro, H. N., Academic Press, New York and London, p. 125.

4) Stipanuk, M. H. (1979): Effect of excess dietary methionine on the catabolism of cysteine in rats. J. Nutr., 109, 2126-2139.

5) Daniels, K. M., and Stipanuk, M. H. (1982): The effect of dietary cysteine level on cysteine metabolism in rats. J. Nutr., 112, 2130-2141.

6) Stipanuk, M. H., and Rotter, M. A. (1984): Metabolism of cysteine, cysteine-sulfinate and cysteinesulfonate in rats fed adequate and excess levels of sulfur-containing amino acids. J. Nutr., 114, 1426-1437.

7) Yamaguchi, K., Sakakibara, S., Asamizu, J., and Ueda, I. (1973): Induction and 
activation of cysteine oxidase of rat liver: II. The measurement of cysteine metabolism in vivo and the activation of in vivo activity of cysteine oxidase. Biochim. Biophys. Acta, 297, 48-59.

8) Hosokawa, Y., Niizeki, S., Tojo, H., Sato, I., and Yamaguchi, K. (1988): Hepatic cysteine dioxygenase activity and sulfur amino acid metabolism in rats: Possible indicators in the evaluation of protein quality. J. Nutr., 118, 456-461.

9) Tanaka, H., Yamaguchi, M., and Kametaka, M. (1974): Body composition and utilization of protein and energy in growing rats at different dietary energy ratios by use of purified whole egg protein. Agric. Biol. Chem., 38, 1113-1120.

10) Tanaka, H., Yamaguchi, M., and Kametaka, M. (1975): Metabolism of leucine and alanine in growing rats fed the diets with various protein to energy ratios. Agric. Biol. Chem., 39, 507-514.

11) Tanaka, H., Yamaguchi, M., and Kametaka, M. (1976): Metabolism of serine in growing rats and chicks at various dietary protein levels. Agric. Biol. Chem., 40, 11191127.

12) Tanaka, H., and Ogura, M. (1980): Metabolism of histidine in growing rats at various dietary protein levels. Agric. Biol. Chem., 44, 2343-2349.

13) Tanaka, H., Ohyama, M., and Ogura, M. (1984): Metabolism of arginine, proline and glutamic acid in growing rats at various dietary protein levels. Agric. Biol. Chem., 48, 2731-2738.

14) Tanaka, H., Nakatomi, Y., and Ogura, M. (1987): Metabolism of phenylalanine, tyrosine and aspartic acid in growing rats at various dietary protein levels. Agric. Biol. Chem., 51, 499-505.

15) Tanaka, H., Nakatomi, Y., and Ogura, M. (1987): Metabolism of glycine and threonine in growing rats at various dietary protein levels. Agric. Biol. Chem., 51, 3087-3093.

16) Tanaka, H., Fukushima, T., Nakatomi, Y., and Ogura, M. (1988): Metabolism of valine and isoleucine in growing rats at various dietary protein levels. Agric. Biol. Chem., 52, 811-817.

17) Tanaka, H., Nakatomi, Y., Mori, M., and Ogura, M. (1990): Metabolism of methionine and cysteine in growing rats at various dietary protein levels. Agric. Biol. Chem., 54, 2093-2099.

18) Tanaka, H., Nakatomi, Y., Takahashi, K., and Ogura, M. (1991): Metabolism of lysine and tryptophan in growing rats at various dietary protein levels. Agric. Biol. Chem., 55, 811-817.

19) Tanaka, H., Takahashi, K., Mori, M., and Ogura, M. (1991): Metabolism of asparagine and glutamine in growing rats at various dietary protein levels. Agric. Biol. Chem., 55, 1867-1872.

20) Yamaguchi, M., and Kandatsu, M. (1973): Nutritional evaluation of dietary proteins with regard to body protein metabolism in adult rats using purified whole egg protein as a standard reference. Agric. Biol. Chem., 37, 809-817.

21) Miller, D. S., and Payne, P. R. (1961): Problems in the prediction of protein values of diets. The influence of protein concentration. Br. J. Nutr., 15, 11-19.

22) Kawakami, M., and Shimura, K. (1972): A new scintillator in liquid scintillation counting and a simplified method of sample preparation for determination of tritium and carbon-14. Radioisotopes, 23, 81-87. 
23) Folch, J., Lee, M., and Sloane-Stanley, G. H. (1957): A simple method for the isolation and purification of total lipids from animal tissues. J. Biol. Chem., 226, 497 509.

24) Yoshida, M. (1975): Design of Experiments of Animal Husbandry, Yokendo Co., Tokyo, p. 84.

25) Benjamin, L. E., and Steele, R. D. (1986): The effect of dietary protein and sulfur metabolism in portacaval-shunted rats. J. Nutr., 116, 59-69. 